\title{
The urgency of Zakat on Income Management for Gorontalo Community Empowerment
}

\author{
Nur Mohamad Kasim \\ \{nurkasim76@yahoo.co.id\} \\ Universitas Negeri Gorontalo, J1. Jenderal Sudirman No.6, Dulalowo Tim., Kota Tengah, Kota \\ Gorontalo, Gorontalo, 96128, Indonesia
}

\begin{abstract}
The purpose of the research is to explain the substance of zakat on income regulation, to examine the government role in the management, utilization, and the importance of zakat on income management. Furthermore, the study aims to determine and analyze the constraints that obstruct the management of zakat on income in Gorontalo.The research is socio-legal research, which uses a qualitative analysis technique.The data is comprised of primary and secondary data. This research used the legislation, law concepts or theories, and case approach. Moreover, the research employed literature review, observation, and interview as the data collecting techniques.The results showed that the management of the zakat on income in Gorontalo is still low. There is a substantial weakness in the management of zakat on income, as the existing regulation has not accommodated the interest of the Islamic community, especially those who are obligated to giving zakat. Meanwhile, there are a lot ofprofessional groupswho are not aware of the obligation of giving their zakat on income. Hence, there is a necessity to penalize those who did not obey the regulation to raise awareness in the importance of paying zakat. Other factors that affect such phenomena are the lack of reliable and professional human resources as well as less supervision from the government.Also, the lack of community awareness of zakat on income culture and government role in zakat distribution result in low attention on the management of zakat on income. Zakat on income can empower the less fortunate people by underlying the importance of zakat on income management and by doing a proper administrationof the process of collecting, distributing, utilizing, as well as enhancing theprocess of zakat on income. Also, the management of zakat on income must be done as professional, transparent, and proportional as possible. Therefore, it can give a positive contribution to the local government, especially the National Zakat Board or Badan Amil Zakat Nasional (BAZNAS) of Gorontalo Province.
\end{abstract}

Keywords: Zakat Law, National Zakat Board Income Management, Community Empowerment, Gorontalo

\section{Introduction}

The management of zakat is based on the Act No. 38 of 1999 about the Management of Zakat which is considered to be no longer appropriate by the times and legal needs in society and therefore needs to be replaced. Act No. 23 of 2011 about the Management of Zakat, which replaces the former act has become a reasonable basis for managing zakat in Indonesia. Today, the development of zakat is quite dynamic, and hopefully, zakat can play a role in increasing the economy of the society and the poverty alleviation in the future.

In the modern era, the progress of human civilization has given a diverse impact on human livelihood. Agricultural occupations were abandoned and considered less attractive. The most visible form of today's income is the income that is obtained through one's professions. The professions may be in the forms of employment (private or public), or occupations that do not 
depend on others (professionals), such as doctors, advocates, tailors, artists, and so on. This type of jobs earns income either in the form of salary, wage, or even honorarium.

Zakat on income or sometime also known as profession zakat as well as zakat on salary is a term that emerges nowadayswhich the Salaf cleric (Salaf clericis mention to the first generation of Muslims) calls by the term al-mal al-Mustafa, which is zakatincluded inal-mal al-Mustafa (Inal-mal al-Mustafais zakat on income in the field of commerce). This type of zakat is taken from income generated from professions such as salaries of employees, consultants, doctors, and others or unexpectedly generated sustenance such as sweepstakes and a quiz prize. Zakat on income has been a debate for a long time. Those who oppose zakaton income argued that there is no clear or vigorous argument and no specific concrete example from the Sunnahof the Prophet Muhammad SAW. However, those who agree and support the zakat on income assume that the actual zakat on income is not a new thing in Islam, in which the source is so clear and vigorous from the Quran[1].Zakat is commonly considered as an essential alternative to solving one of the most prevalent social and economic problems in the world, namely poverty[2]. Zakat is not considered a personal matter even though it is given by personal consciousness because zakat is a right and obligation of every Muslim[3].In the early twentiethcentury, the existence of zakat on income has become widely recognized. Thisis markedby the emergence of a great contemporaryscholar and highly prolific writer of Egyptian masyhurasal, Yusuf al-Qardawi[2]. His books became the relevant references of Muslims in the world and gave a significant influence on the development of discipline related to zakat, including zakat on income.

The distribution of zakat property can be done privately or regularly through the aid of amil zakat institutions that have the authority to conduct activities in collecting and distributing the zakat property to the groups who deserve to receive it. The use of institutional zakat authority is to achieve its ethical objectives for social justice purpose based on the ideals of spirituality[3].

The potential of zakat will continue to grow along with the increasing number of employees of state-owned enterprises, along with private and civil servants so that the poor community can feel the benefits of zakat and thus the economic independence can be raised. The point is that zakat can help the government in alleviating poverty. This is aligned with the purpose of zakat management that is professional, responsible, and legally conducted by the government with the community.

The zakat is also supported by the Act Number 23 of 2011 on Zakat Management and Presidential Instruction No. 3 of 2014 on Optimizing Zakat Collection. Currently, some ministry employees have implemented their zakat obligations according to Presidential Instruction No. 3 of 2014. The zakat of the employees is paid by deducting $2.5 \%$ of their monthly salary[4]. Thisis also followed by most of thecivil servants in Gorontalo. The zakat requirement is also included in Gorontalo Governor Regulation No. 7 of 2014 on the Collection of Zakat in the Government of Gorontalo Province.Due to the importance of the regulation on the management, the government of Gorontalo province issued a decree in the form of governor's regulations that are binding to the people of Gorontalo, especially the muzakki.

It is also explained in the government regulation that the subject and object of zakat collection is the muzaki which consists of the civil servant's candidates and officials within the scope of the Government of Gorontalo province. Their calculation of income has fulfilled the obligation to pay zakat, and that the object of zakat is the revenue derived from the profession as civil servant candidates and officials[5].

The zakat collection case is done within the Government of Gorontalo Province and conducted 
by Local Government agencies spending treasurer with the calculation of $2.5 \%$ from the net salary of civil servant candidates and officers' allowance received every month and hasbeen registered on payroll list[5]. The Governor Regulation No. 7 of 2014 on Zakat Collection in Gorontalo Province Article 4 that: "(1) Collection of zakat within the Provincial Government of Gorontaloconducted by the local government agencies Expenditure Treasurer.; (2) The amount of zakat collection as referred to in paragraph (1); $2.5 \%$ of civil servant's salary and officer's allowance received every month listed on the payroll; (3) Prior to zakat collection by treasurer as referred to in paragraph (2) of each muzzaki make a statement of willingness to issue the zakat deducted from Civil Servant salary and official allowance every month.; (4) A statement of willingness as referred to in paragraph (3) listed in the attachment of this Regulation"; (5) The result of zakat collection by the treasurer as intended in paragraph (2) shall be deposited to the Provincial Baznas account at the Gorontalo Syariah Mandiri Bank with Account Number 7025980268 and Account Number 7035159047; (6) Apart from the zakat as referred to in paragraph (2) Muzzaki which will issue Infak and Zedekiah, then it can deposit directly to the local agencies treasurer or able to depositdirectly to the Provincial Baznas account; (7) Upon collection of zakat as referred to in paragraph (2) and zakat deposit to Baznas as intended paragraph (5), the Spending Treasurer reports to: a). National Zakah Board of Gorontalo Province, b). Head of Bureau of Public Welfare Secretariat of Gorontalo Province, c). Head of local government agencies within the Provincial Government of Gorontalo.

The problems often arise in collecting the zakat on income in the Gorontalo Provincial Government and the Regency/City Government. The problems result from the implementation of collecting the zakaton the income of civil servants/civil servant candidates and officials who have become fixed muzaki, which slow down the distribution of zakat funds from local government agencies. The zakat fromevery institution is forwarded to the Institution of Amil Zakat and distribute it to the mustahik or the recipients who must receive the zakat. Along with the increase in the poverty rate, the number of zakat or mustahik recipients is also increased. The data obtained by the researchers in the field, for Gorontalo Province with a population of 1.2 million, the mustahik number of zakat recipients is 611.274 people. This is a severe issue that the local government must address. Without the help of zakat on income, thesick society (underprivileged) will not be able tocope with their everyday life. In this case, zakat is essential to help them.

\section{Methodology}

This research will review and analyze the legal issues related to the research on the urgency of zakat on income management for Gorontalo community empowerment. This study used a legal, conceptual, and legal theory as well as case approach. The research utilized literature, observation, and interviews as data collection techniques.

The approach of this research is the normative, sociological, and philosophical approach. The approaches used in this research are:

First, the statute approach. The use of this approach in normative research is imperative because, by relevant law, the focus of normative research is on research on written legal materials (written law).

Second, the conceptual approach. The relevance of this approach is essential as it concerns with the regulation, policy strategy, and perception of the zakat on income. Policy-makers need to update the concept, so it will have consequences on the expansion of new theories in Islamic law in order to effectively support the implementation zakat on income in Gorontalo. 
Third, the philosophical approach of law. The use of this approach is to seek and analyze the legal principles implicit in the legal arrangement of zakat on income and philosophy which will become the foundation of the scholars in giving the fatwa to realize the welfare of a just and equitable society.[6]

\section{Findings}

\subsection{Zakat Management Based On Act Regulation}

It has been discussed previously that zakat is includedin a group of religious laws or is called thediyani law. However, based on the reality in Indonesia, the regulationdoes not only regulate the management of zakat but also enters the substance of the law of zakat itself. This means that zakat worship is not only normative/serviced, but also formally juridical/Qadhafi asthe law regulating it. The intended Act is Act No. 23 of 2011 on Management of Zakat.

ActNo. 23 of 2011 is the replacement of Act No. 38 of 1999 on the Management of Zakat which is already in effect. In consideration of the Act. No. 23 of 2011 article states that Act No. 38 of 1999 on the Management of Zakat is not by the development of legal needs in society, so it needs to be replaced. This is the government's consideration to replace the Act No. 38 of 1999 with the Act No. 23 of 2011, to adjust based on the condition and the situation of the people of Indonesia which is always dynamic and evolvingalong with the times, as a result of globalization and modernization. Therefore, the zakat act must also be changed and updated according to the needs of the Indonesian people nowadays.

Article 1 Sub-Article, a ofActNo. 23 of 2011, states that: "the management of zakat is the activity of planning, executing and coordinating in the collection, distribution, and the utilization of zakat." While the purpose in article 3 of Act No. 23 of 2011 is as follows:

a. Improving the effectiveness and efficiency of services in the management of zakat, and

b. Increasing the benefits of zakat to create the welfare of society and poverty alleviation.

\subsection{The Implementation Of Zakat On Income For The Community Empowerment}

The ups and downs of the implementation of zakat on income in Gorontalo are due to the policy on zakat management regulation that has not been maximized, thus affecting the implementation of its management. The implementation of zakat based on a precise regulation is essential to place public or private employees as the subjects. Civil servants or other professions, who have high income as those who are obliged in the payment of zakat, can be used for the benefit of other people. This is aimed to improve the welfare of the poor[7].

The presence of Act No. 23 of 2011 on the Management of Zakat has given widespread implications for its management institutions. The payment of Zakat is expected to be entrenched in a capable Muslim society and can be functioned optimally as the essential instrument of economic empowerment of people and nation[8].Similarly, Act No. 38 of 1999 on the Management of Zakat is very relevant to the provisions of Islamic law, where the management of zakat is entirely submitted to the government. Nevertheless, in the implementation of this zakat management, the government is not doing this alone. The government has the power and has the authority to compel the obligatory zakat to give their property and set aside some of their income for the benefit of many people as done by Prophet Muhammad's companions. 
Such practices should be undertaken and followed by most civil servants or private employees or people with other professions in Gorontalo so that the management of zakat is more leverage and professional. This is similar to the results of the interview with the Head of Economic Section Zulbahri Yusuf, ST., MT. on April 14, 2017, that the zakat deductions by the local government have been made well. Though there are still obstacles encountered, especially in terms of understanding the obligation to give zakat, which is still personal, and the report on zakat funds distribution has not run optimally. The circumstances have encouraged regional Baznas institutions to be more efficient in managing zakat, so there will be no more competition in collecting zakat, and there will be no more overlaps in zakat distribution. Furthermore, there will be no different information to the muzakki in depositing their zakat. This will be done as an effort to grow trust and curb the data as the form of accountability.

As the effort for actualizing the proper and professional management of zakat by the provisions of religion, it requires excellent and perfect law enforcement with law enforcement officers who have sufficient moral or faith quality, are willing to sacrifice with high dedication and have a great responsibility to the interests of many people. According to Jeremy Bentham, the purpose of the law is to create happiness formany. The existence of the state and the law is solely for the sake of the real benefit of people's happiness[9].Firmly, according to this theory, the ideal society is a society that tries to increase happiness and minimize unhappiness. It also means a society that attempts to give happiness to the people in general, so that the unhappiness can be kept to a minimum. Happiness means pleasure or lack of misery; unhappiness means misery and lack of pleasure.

Therefore, to achieve happiness for many people, it is essential is to fulfill the obligation of zakat for those who are capable. The zakat management should also be supported by a pleasant and professional procedure based on the provisions of sharia. In order to avoid inequality on the implementation of zakat management function, it is expected that National Zakah Board of Gorontalo or Badan Amil Zakat Nasional (BAZNAS) institution can channel the right program to the needy and give information related to zakat management, with the hopes that the management of zakat in the future will be improvedto fulfill the prosperity of society. Also, zakat management should be equipped with zakat financial management regulation as well. If the regional financial management model guides the zakat financial management mechanism, financial management can be carried out in proper order. Zakat funds can be appropriately managed if the managing agency has a reliable funding mechanism.

Meanwhile, related to the management of zakat fund, there should be a synergy between the central government, local government, National Zakah Board in advancing and developing the management of this charity from a social institution into a sharia financial institution. This can be done solely to make the management of zakat funds tobe more transparent and accountable following the provisions of sharia.

\section{Conclusion}

The problem of zakat management, especially zakat on income, is quite complicated, in which it has become the problem faced by all Muslims nowadays, especially for the muzakkias the zakat payer. The importance of building Muslim solidarity through zakat on income as its strength in promoting and improving the welfare of society to create awareness that zakat on income is efficient and useful for the community. 
The realization of zakat management in Gorontalo does not seem to run effectivelybecause the open management of zakat management is still experiencing several difficulties, particularly on the mechanism of collecting and distributing the zakat. Also, those who are obliged of zakat on income appear to be reluctant to pay zakat through National Zakah Board. There are still concerns about the muzakkiregardingthe distribution of zakat and the lack of information to the public.

\section{ACKNOWLEDGMENTS:}

In conducting this research, the research team got help from various parties, and also overcome obstacles in the implementation of research activities. For that, the researchers express sincere gratitude to the parties as follows:

a. Gorontalo Provincial Government (Gorontalo Regency, Boalemo Regency, and Gorontalo City) who have helped and participated in this research activity;

b. Rector of State University of Gorontalo and Chairman of the Institute of Research and the Community Service State University of Gorontalo that have agreed and facilitate and facilitate the process of implementation of this research activity;

c. National Zakah Board or Badan Amil Zakat Nasional (BAZNAS) of Gorontalo Province;

d. National Zakah Board or Badan Amil Zakat Nasional (BAZNAS) of District Boalemo.

e. All parties who have assisted this research activity, so that this research can be appropriately implemented.

Hopefully, this research can give a positive contribution to the local government of Gorontalo Province in order to realize the society that is aware of its obligation to zakat profession.

\section{References}

[1] A. Jaelani, "Zakat Accounting: Metaphor and Accounting Treatment for Business Organization," SSRN Electron. J., 2016.

[2] M. Akhyar Adnan and N. Barizah Abu Bakar, "Accounting treatment for corporate zakat: a critical review,” Int. J. Islam. Middle East. Financ. Manag., 2009.

[3] N. A. Mubtadi and D. Susilowati, "Analysis of Governance and Efficiency on Zakat Distribution: Evidence from Indonesia," Int. J. Zakat, vol. 3, no. 2, pp. 1-15, 2018.

[4] Fakhruddin, Fiqh dan Manajemen Zakat di Indonesia. Malang: UIN Malang, 2008.

[5] D. Hafifuddin, Agar Harta Berkah dan Bertambah. Jakarta: Gema Insani Press, 2007.

[6] R. Setyowati, L. Abubakar, and N. Rodliah, "SHARIA GOVERNANCE ON ISLAMIC BANKING: SPIRITUAL RIGHTS PERSPECTIVE ON CONSUMER PROTECTION IN INDONESIA,” Diponegoro Law Rev., 2017.

[7] M. F. Mas'udi, Risalah Zakat Dalam Islam. Jakarta: Pustaka Firdaus, 1993.

[8] H. ALi, "Peran Strategis Zakat Dalam Masterplan Arsitektur Keuangan Syariah Indonesia." National Zakat Board, Jakarta, 2016.

[9] M. Hadi, Problematika Zakat Profesi dan Solusinya Sebuah Tinjauan Sosiologi Hukum Islam. Yogyakarta: Pustaka Pelajar, 2010. 